\title{
O ENSINO DO PROJETO FRENTE ÀS MUDANÇAS TECNOLÓGICAS: O CASO DA EAU/UFF
}

\author{
DINIZ, Luciana \\ PPGAU/UFF, e-mail: fluciana_nemer@ig.com.br \\ QUEIROZ, Joana \\ PPGAU/UFF, e-mail: joanacmiranda@gmail.com
}

\begin{abstract}
RESUMO
O presente trabalho é fruto da pesquisa do Mestrado que está sendo desenvolvida no programa de Pós-graduação em Arquitetura e Urbanismo da Universidade Federal Fluminense que foi iniciado em 2018, e se encontra em fase de qualificação. Sua temática analisa as alterações projetuais frente às mudanças que impactaram as formas de concepção arquitetônicas e urbanísticas nas últimas décadas. Na Escola de Arquitetura e Urbanismo da Universidade Federal Fluminense, o ensino de projeto no ateliê imprime em suas práticas, o reflexo dessa evolução, no entanto, tem apresentado indícios de defasagens em relação às novidades tecnológicas: na adequação dos ambientes; na capacitação de seus professores e na inserção de novas ferramentas digitais. Este artigo tem como objetivo o registro da evolução e a adequação dos recursos digitais de apoio ao projeto como exercício acadêmico. Quanto aos procedimentos técnicos, foram feitas consultas em fontes secundárias e primárias. Através de pesquisa bibliográfica buscou-se o estado da arte no assunto. E, em campo, foram analisadas as estações de trabalho e realizada a coleta de depoimentos. Os primeiros resultados apontam para práticas pedagógicas ainda desatualizadas no que tange a tecnologia. Deste modo, pretende-se contribuir para a discussão da evolução digital no ambiente de ensino.
\end{abstract}

Palavras-chave: Arquitetura, Ateliê, Ensino de projeto, Ferramentas digitais, Tecnologia.

\begin{abstract}
This The present work is the result of the Master's research that is being developed in the Graduate Program in Architecture and Urbanism of the Fluminense Federal University, which was started in 2018 and is in the qualification phase. Its theme analyzes the changes in the design of the changes that have impacted the architectural and urbanistic forms of conception in the last decades. In the School of Architecture and Urbanism of the Fluminense Federal University, the professors of project in the studio realize in yours practices, the reflection of this evolution, however, has presented signs of lags in relation to the technological innovations: in the adaptation of the environments; in the training of their professors and in the insertion of new digital tools. This article aims to record the evolution and appropriateness of digital resources to support the project as an academic exercise. As for the technical procedures, consultations were made on secondary and primary sources. Through bibliographic research, the state of the art was sought in the subject. And, in the field, the workstations were analyzed and the interviews were collected. The first results point to pedagogical practices still outdated when it comes to technology. In this way, this article is intended to contribute to the discussion of digital evolution in the teaching environment.
\end{abstract}

Keywords: Architecture, Atelier, Design Teaching, Digital Tools, Technology.

DINIZ, L.; QUEIROZ, J. O Ensino do projeto frente às mudanças tecnológicas: o caso da EAU/UFF. In: SIMPÓSIO BRASILEIRO DE QUALIDADE DO PROJETO NO AMBIENTE CONSTRUÍDO, 6., 2019, Uberlândia. Anais... Uberlândia: PPGAU/FAUeD/UFU, 2019. p 714-730. DOI https://doi.org/10.14393/sbqp19066. 


\section{INTRODUÇÃO}

O processo de trabalho dos arquitetos e urbanistas tem como fator influenciador o desenvolvimento tecnológico. Desse modo, ao longo das últimas décadas, o uso de instrumentos para desenho evoluiu rapidamente da simples substituição da prancheta pelos sistemas CAD, para o uso intensivo do computador e de outros dispositivos, como mesas digitalizadoras e tablets, para a elaboração dos projetos de forma automatizada e otimizada.

Apesar das ferramentas digitais já atenderem a todas as fases do processo criativo, do desenho livre ao desenho técnico, a inserção destas nos ateliês de projeto das Escolas de Arquitetura e Urbanismo ainda é cercada de desafios. Este artigo pretende ampliar o debate sobre as influências da evolução tecnológica no modo de ensinar o projeto, utilizando como exemplo, o caso da Escola de Arquitetura da Universidade Federal Fluminense, que se localiza na cidade de Niterói, estado do Rio de Janeiro. As análises serão feitas por três eixos: 1. A função e evolução do Ateliê; 2. Os desafios para a inserção de ferramentas digitais nesse ambiente; 3 . O impacto do avanço tecnológico na dinâmica do professor/aluno nos ateliês.

Este trabalho parte de dois princípios: o desenho livre é uma ferramenta fundamental para o processo projetivo e a presença da tecnologia é, hoje, irreversível.

\section{REVISAO BIBLIOGRÁFICA}

Para compor esta revisão, selecionou-se onze autores que relacionam em seus estudos arquitetura, tecnologia e contemporaneidade.

Como descrito por Gabriel (2013), as tecnologias alteram o cenário das relações na sala de aula, assim como o ateliê é o local central da formação do arquiteto e urbanista, segundo Martinez (2000), é neste ambiente que acontecem as maiores transformações dentro do curso.

Apesar disso, Florio (2013) entende que o ensino de graduação continua defasado e, a razão disso, segundo Green e Bigum (1995), seria a ausência de reconhecimento e perspectiva dos educadores de que existam novas formas de se obter conhecimento.

Nesse sentido, Wojcickoski (2017) acredita que nunca foi intenção substituir o croqui pelo computador. Muito pelo contrário, Veloso e Rufino (2005) afirmam que projetar com o auxílio do computador representa flexibilidade.

Em relação ao croqui, Claro e Jordão (2014) concordam que atualmente existem ferramentas digitais que podem ser usadas para a sua confecção. Nesse sentido, Castral e Vizioli (2011) defendem que tablets atuais já simulam o traço no papel e, para Botasso e Vizioli (2017), este dispositivo possibilita ao desenho grande armazenamento.

Carvalho e Savignon (2012) citam alguns equipamentos que fariam do ateliê de projetos um ambiente atualizado segundo a tecnologia. Dertouzos (2000) garante que a educação é o fator motivador da vontade de aprender e na criação de vínculos em sala de aula.

Portanto, nesse presente artigo, ao se utilizar desses e de outros argumentos, será feita a análise do caso da EAU/UFF em relação às influências da tecnologia em seus ateliês de projeto. 


\section{METODOLOGIA}

No presente artigo foi adotada a Pesquisa Qualitativa e, como método, o Estudo de Caso. A coleta das informações foi feita por meio de registros fotográficos, aplicações de questionários e entrevistas in loco.

Os questionários foram elaborados para dois grupos distintos de respondentes da EAU/UFF: professores e estudantes. Como a temática do artigo se baseia na evolução da tecnologia, cuja característica principal é a efemeridade, foi determinado um recorte temporal mais recente, de 2009 a 2019. Dessa forma, somente foram entrevistados professores que atuaram e alunos que ingressaram a partir de 2009 na EAU/UFF.

O questionário foi enviado para cerca de setenta professores e oitenta alunos, trinta professores e trinta e dois alunos responderam.

Foi criado um sistema de letras para identificar os relatos dos respondentes, assim o sigilo da identidade, como acordado quando da aplicação dos questionários, foi garantido.

Após o levantamento das informações e conjuntamente com o aporte teórico extraído da revisão bibliográfica, foi feita a análise por meio de comparação e compilação dos dados entre si.

\section{RESULTADOS E DISCUSSÕES}

\subsection{Ateliês de projeto: tradição x evolução}

O Ateliê de projetos é o centro do ensino do projeto nas Escolas de arquitetura e urbanismo. "Essa disciplina é o tronco do currículo, (...) é a parcela mais específica da formação" (MARTINEZ, 2000, p. 55), em comparação, Gabriel (2013) afirma que as inovações tecnológicas exercem influência nestes ambientes ao alterar as relações humanas.

Segundo Wojcickoski (2017), o uso de ferramentas digitais nos ateliês acontece de forma progressiva ao avanço das disciplinas, porém somente focada na representação gráfica. Dessa forma, Claro e Jordão (2014) acreditam que o aluno não faz um uso reflexivo dos novos recursos tecnológicas. "Para mim, o conhecimento digital diz respeito à uma forma de representação da ideia do objeto" (GEAL, 2019, Professor-respondente).

No sentido oposto, Veloso e Rufino (2005) acreditam que projetar com o auxílio do computador significa flexibilidade, visto que são muitos os procedimentos possíveis dentro do universo digital, como copiar, colar, apagar, etc,. Todavia, alguns professores da EAU/UFF se mostram cautelosos quanto a disponibilização de ferramentas computacionais nos ateliês iniciais do curso, onde o estudante ainda está pouco familiarizado com o traço.

O debate deve ser permanente, contemplar a atualização do conhecimento sobre o uso dos recursos e trazer a ponderação do que deve estar disponível para os alunos em formação, sem prejuízo da representação manual, original e criativa propiciada pelo desenho livre (MLPMC, 2019, professorrespondente).

Nas disciplinas iniciais de projeto, nós professores entendemos que a maquete física e os croquis precisam ser dominados 
antes de os alunos começarem a utilizar ferramentas digitais (MRF, 2019, Professor respondente).

Por outro lado, mesmo nos primeiros ateliês, o uso de tablets parece não influenciar a apreensão do traço, pois apesar de se tratar de uma ferramenta digital, Castral e Vizioli (2011) defendem que as versões atuais desses dispositivos reconhecem as sensações de tato, criando assim uma similaridade com o desenho manual. Botasso e Vizioli (2017) incentivam o uso desse recurso, visto a possibilidade de grande armazenamento e posterior edição através de outros softwares.

Em uma das disciplinas que leciono, no segundo período, os estudantes são estimulados a utilizarem recursos digitais em montagens e/ou tratamento de imagens, mas somente a partir do próprio conhecimento. Seria muito bom se pudéssemos incorporar mais tais recursos (RLDT, 2019, Professorrespondente).

Em todo o tempo que estou na faculdade (mais de 4 anos) presenciei somente dois alunos utilizando tablets, os professores não incentivam o uso durante as aulas $(\mathrm{PH}, 2019$, Alunorespondente).

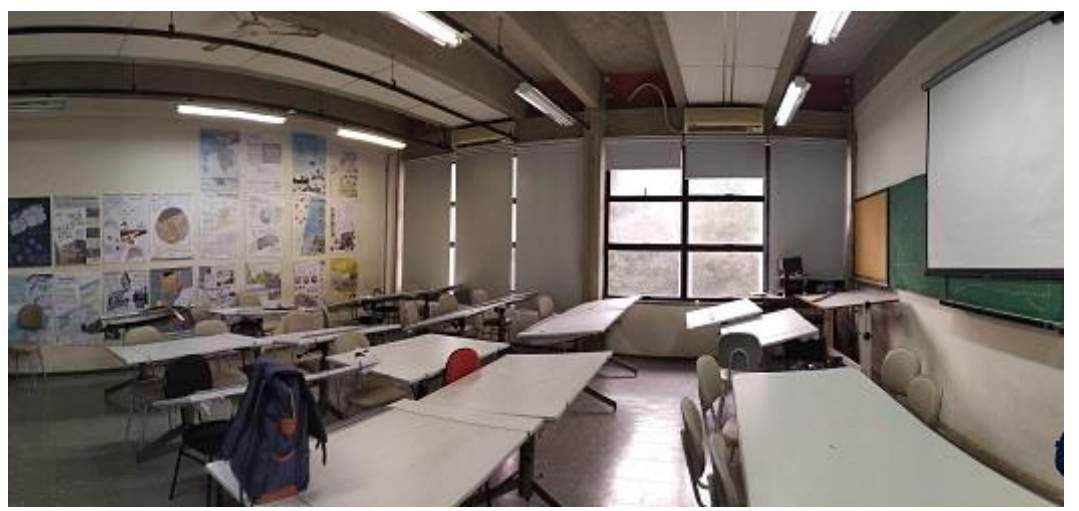

Figura 1 - Ateliê destinado às disciplinas intermediárias e/ou terminais do curso com pranchetas e bancada -

Fonte: Autora Queiroz (2019)

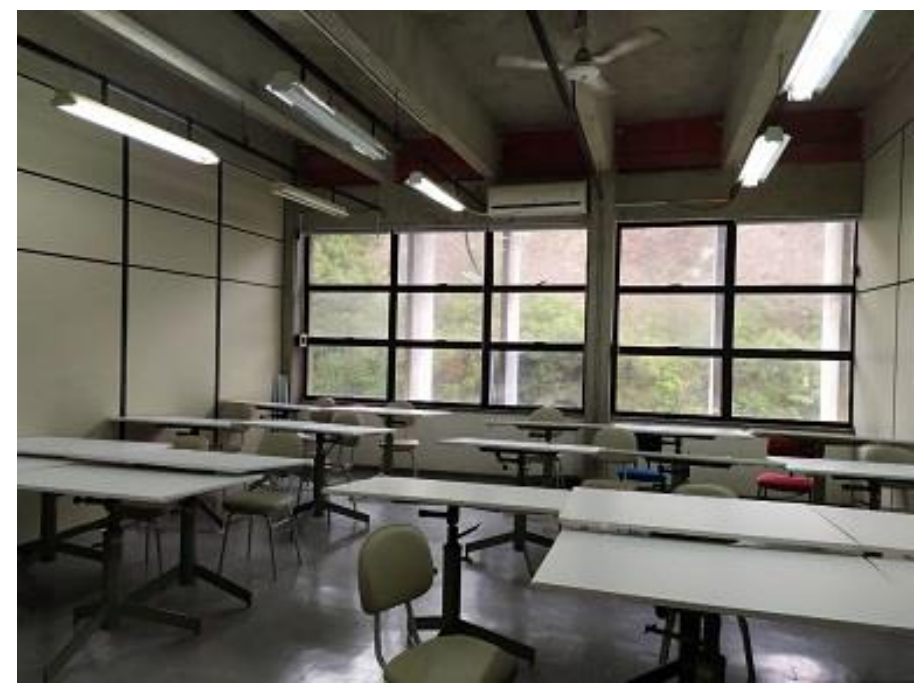

Figura 2 - Ateliê destinado às disciplinas intermediárias e/ou terminais do curso equipados exclusivamente com pranchetas -

Fonte: Autora Queiroz (2019) 


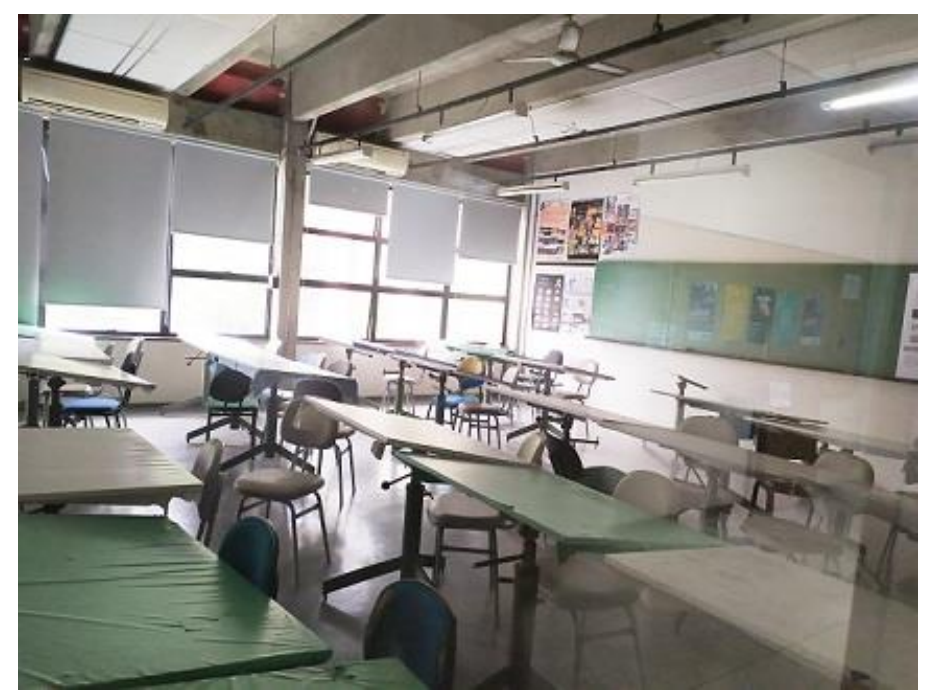

Figura 3 - Ateliê destinado às disciplinas iniciais do curso equipados exclusivamente com pranchetas -

Fonte: Autora Queiroz (2019)

Quanto aos ateliês da EAU/UFF nos períodos iniciais do curso, são destinadas salas maiores, já nos intermediários e finais do curso, salas menores (Figuras 1 a 3).

Os equipamentos disponibilizados nesses ambientes, conforme relatado pelos alunos-respondentes (Gráfico 1), são em sua maioria pranchetas, apesar de em um ateliê haver uma grande bancada (Figura 1) e nota-se a ausência de computadores fixos. Quadros de giz ainda se encontram em maior número do que quadros brancos. Equipamentos como Datashow, quando são usados, precisam ser retirados na secretaria, a título de empréstimo, assim como computadores, porém como são poucos, os alunos precisam levar os seus próprios.

Nos ambientes de ensino não são disponibilizados de forma fixa datashows e computadores (a não ser, no laboratório de informática, no caso de computadores). Porém a EAU/UFF empresta, conforme solicitação prévia na secretaria, em quantidade limitada (ACA, 2019, Aluno-respondente).

Não há disponibilização de internet nos ambientes de ensino, conforme relato: "Meus alunos trabalham em seus próprios computadores, seria bom se tivéssemos wifi, pelo menos eles conseguiriam trabalhar com os celulares" (ALVS, 2019, Professor respondente). Informações obtidas na secretaria da EAU/UFF e, por meio de entrevista in loco, citam os equipamentos tecnológicos disponíveis aos alunos e professores (Quadro 1).

Recentemente foram doados 30 computadores e 1 plotter que não foram colocados em uso ainda por falta de espaço. A plotter foi destinada ao DACA', porém além de espaço físico, faltam recursos financeiros para seu funcionamento (PH, 2019, Aluno entrevistado in loco).

\footnotetext{
1 Diretório Acadêmico do curso de Arquitetura e Urbanismo da Universidade Federal Fluminense.
} 

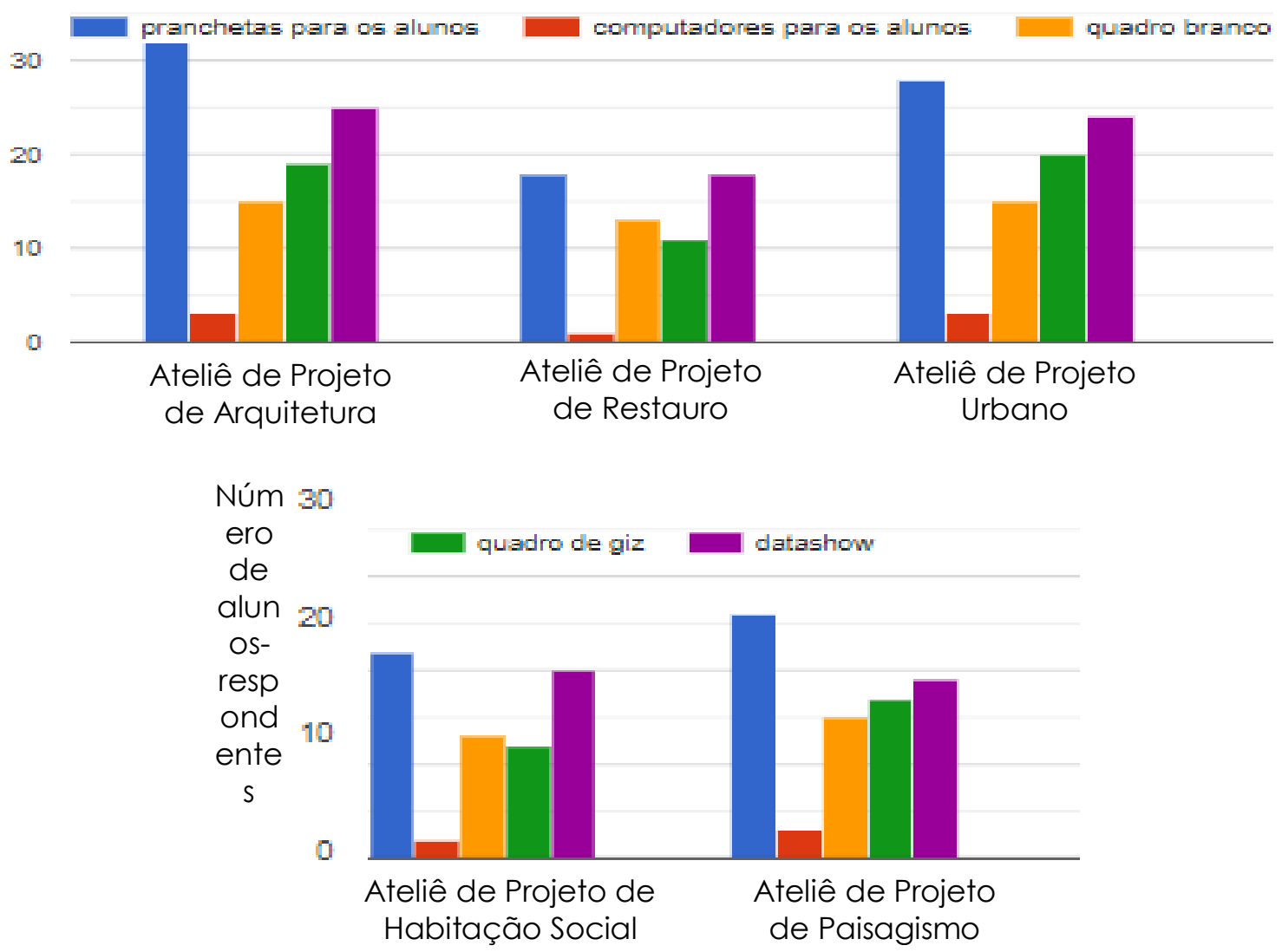

Gráfico 1- Comparação das proporçōes relatadas pelos alunos em relação às ferramentas disponibilizadas pela EAU/UFF nos ateliês -

Fonte: Autora Queiroz (2019)

Quadro 1 - Equipamentos tecnológicos pertencentes a EAU/UFF para apoio às aulas de projeto

\begin{tabular}{|c|c|c|c|c|c|}
\hline Datashow & \multicolumn{2}{|c|}{$\begin{array}{c}\text { Computadores } \\
\text { (notebooks) }\end{array}$} & \multicolumn{2}{|c|}{ Computadores (Deskłops) } & Ploters \\
\hline $\begin{array}{c}\text { Para } \\
\text { empréstimos }\end{array}$ & \multicolumn{2}{|c|}{ Para empréstimos } & \multirow{2}{*}{$\begin{array}{l}\text { Em uso no } \\
\text { laboratório } \\
\text { de } \\
\text { informática }\end{array}$} & \multirow{2}{*}{$\begin{array}{l}\text { Doados para a } \\
\text { Escola, porém } \\
\text { ainda } \\
\text { armazenados } \\
\text { em estoque }\end{array}$} & \multirow{2}{*}{$\begin{array}{c}\text { Doada para o } \\
\text { DACA, porém } \\
\text { ainda } \\
\text { armazenado }\end{array}$} \\
\hline Aos professores & $\begin{array}{l}\text { Aos } \\
\text { alunos }\end{array}$ & $\begin{array}{c}\text { Aos } \\
\text { professores }\end{array}$ & & & \\
\hline 8 unidades & 5 unid. & 5 unidades & 15 unidades & 30 unidades & 1 unidade \\
\hline
\end{tabular}

Fonte: Autora Queiroz (2019)

Os alunos-respondentes apontaram quais são os recursos utilizados pelos professores para ministrarem aulas nos ateliês da EAU/UFF (Gráfico 2), nota-se um uso ainda pouco significativo de recursos tecnológicos.

Quanto as dinâmicas do ensino nos ateliês da EAU/UFF, foi notada em muitos relatos uma mudança gradual de acordo com as progressões nos períodos, contudo ainda assim há professores que mantem a exigência de trabalhos exclusivamente manuais mesmo em períodos mais avançados do curso.

As disciplinas no início do curso tendem a receber trabalhos manuais, enquanto as do final do curso, digitais. Porém, ainda existem professores que insistem em fazer todo o projeto à mão (OVB, 2019, Aluno-respondente). 
O processo da inserção de ferramentas digitais no ensino é complexo, pois depende da superação de alguns desafios, dentre eles: infraestrutura e capacitação digital dos docentes.

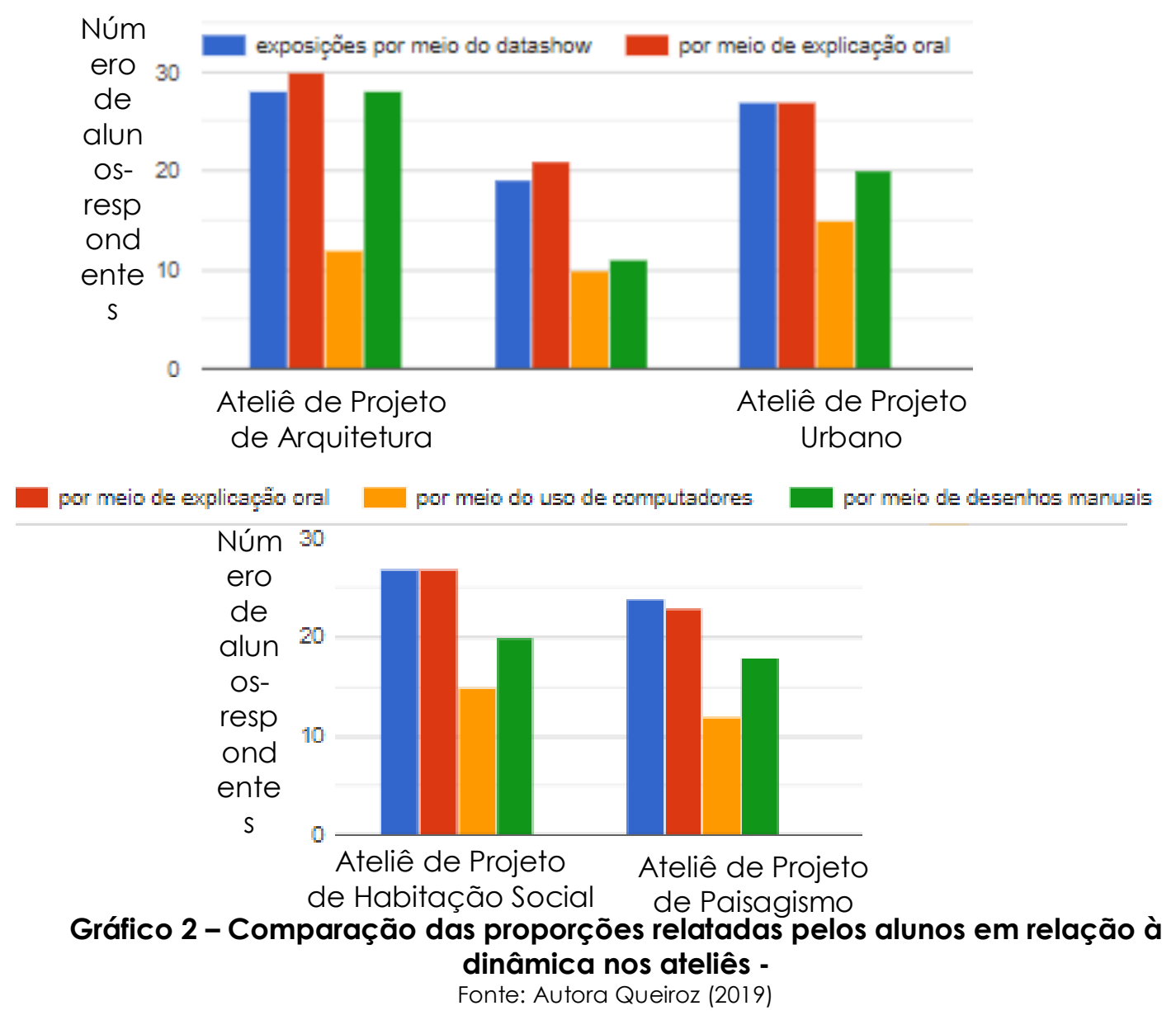

\subsection{O desafio da inserção de ferramentas tecnológicas nos ateliês de projeto}

Segundo Florio (2013), as transformações causadas na arquitetura pela inserção de recursos digitais não conseguiram transformar o ensino de graduação, que continua defasado. Green e Bigum (1995) entendem como justificativa a falta por parte dos educadores de um reconhecimento de que novas formas e maneiras de ver o mundo e de captar conhecimento estão emergindo. Um professor-respondente sinaliza: "Não há por grande parte do corpo docente qualquer estímulo ao uso de tecnologia no projeto. Não há infraestrutura mínima para avançar no ensino digital. Não há interesse em resolver esse problema" (ALVS, 2019, professor-respondente). Nessa lógica Veloso e Rufino argumentam:

No contexto tecnológico, desenvolver a capacidade de projetar e, sobretudo, de ensinar a projetar, é um desafio que exige dos professores e da própria instituição de ensino tanto um esforço de atualização e acompanhamento das novas tecnologias quanto uma mudança de mentalidade na cultura tradicional do ensino de projeto. (VELOSO; RUFINO, 2005, p. 26).

Para professores da EAU/UFF a atualização digital precisa superar o desafio da falta de estímulo dentro da própria instituição: "A atualização agora só é realizada por iniciativa própria de cada professor" (MLPMC, 2019, Professor- 
respondente). Nesse contexto, foi questionada sobre a solicitação de licença capacitação², a maioria (vinte professores) ainda não solicitou, por motivos diversos (Gráfico 3).

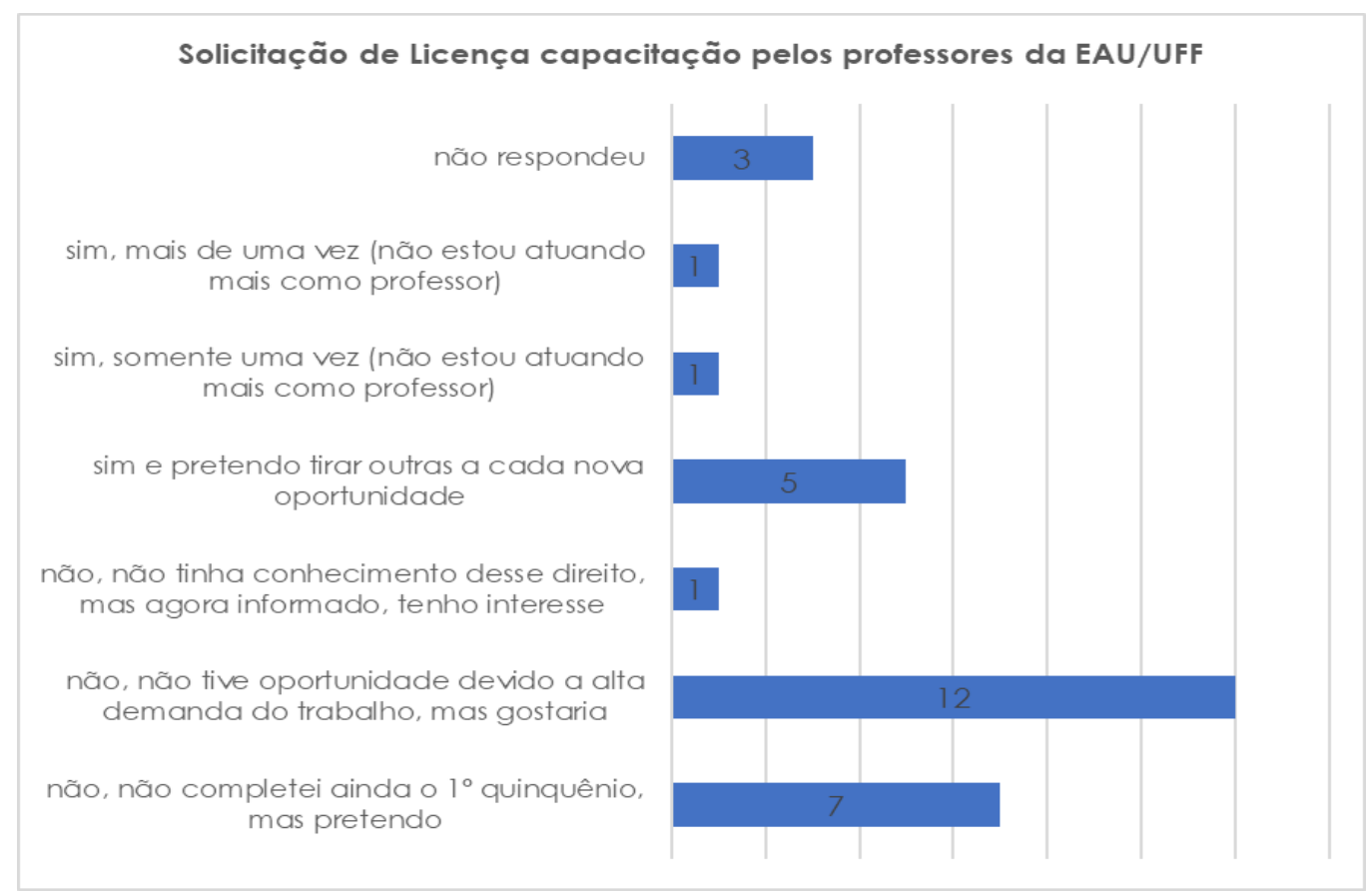

Gráfico 3 - Quantidade de professores que solicitaram licença capacitação Fonte: Autora Queiroz (2019)
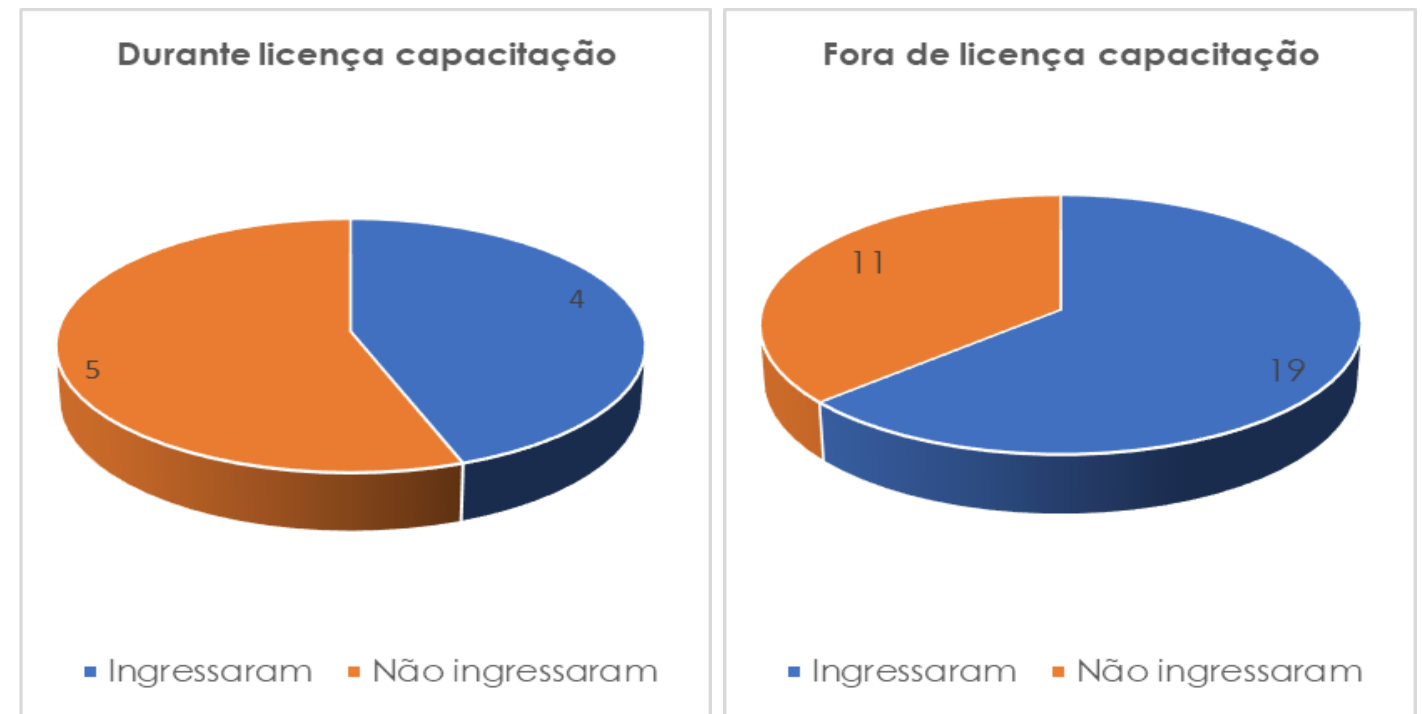

\section{Gráficos 4 e 5 - Quantidade de Professores da EAU/UFF que ingressaram em cursos de ferramentas digitais - \\ Fonte: Autora Queiroz (2019)}

Cerca da metade dos professores que solicitou licença capacitação ingressou em algum curso referente a ferramentas digitais (gráfico 4). Contudo, a

2 Licença capacitação: concedida ao servidor após cada quinquênio de efetivo exercício, a fim de que o mesmo possa afastar-se do exercício do cargo efetivo, com a respectiva remuneração, por até três meses, para participar de eventos de capacitação que contribuam para o desenvolvimento do servidor e que atendam aos interesses da Instituição (BRASIL, 1990). 
maioria ingressou em algum curso referente a ferramentas digitais mesmo fora da licença capacitação (gráfico 5).

Na pesquisa com a EAU/UFF foi traçado o perfil dos professores-respondentes, a maioria ministrou ou ministra aulas de ensino ao projeto (gráficos 6 e 7).
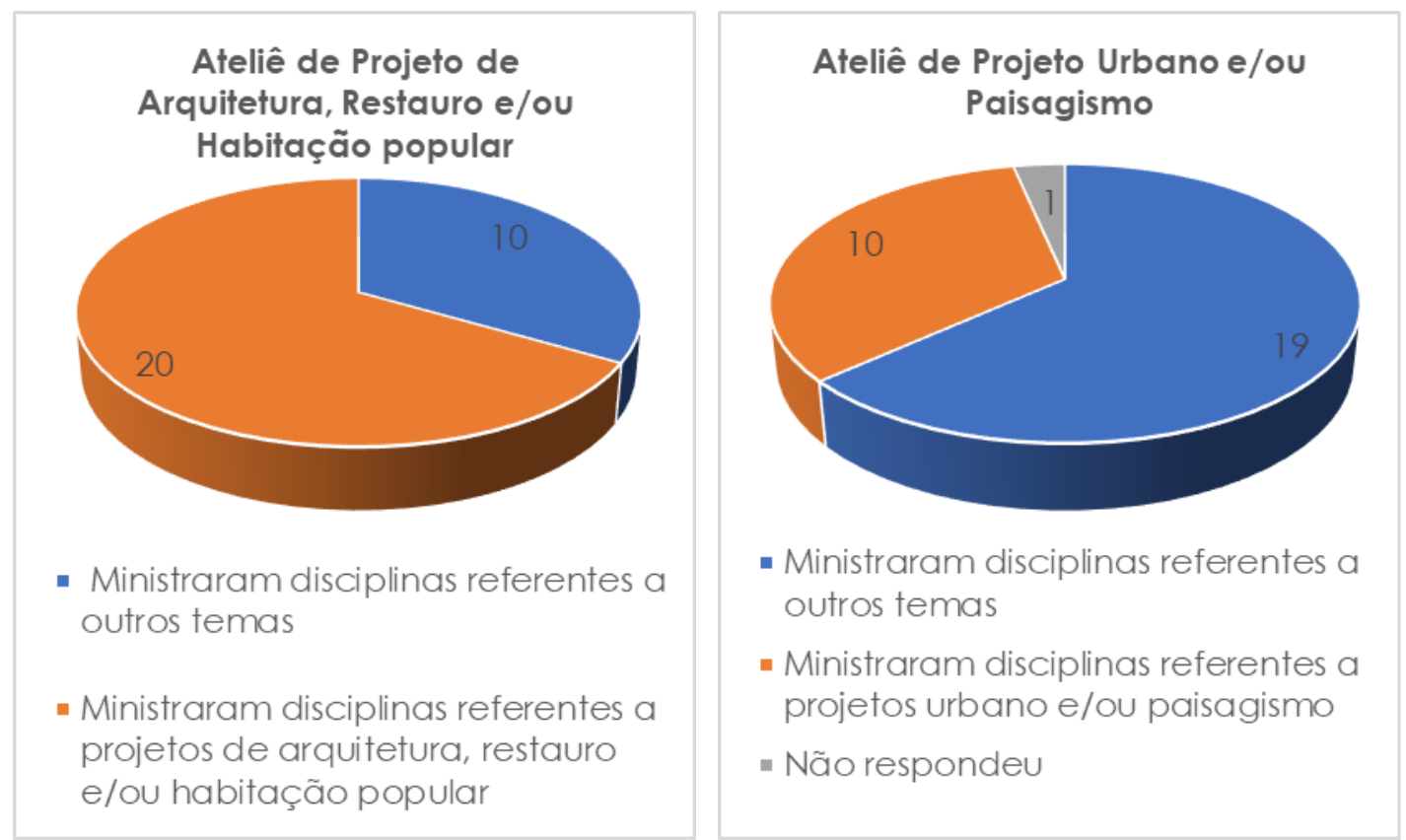

Gráficos 6 e 7 - Quantidade de Professores que lecionaram disciplinas referentes ao ensino do Projeto -

Fonte: Autora Queiroz (2019)

Desses professores, poucos inseriram em seus ateliês ferramentas digitais de apoio ao projeto (gráficos 8 e 9), sendo que alguns professores justificaram essa ausência (gráficos 10 e 11).

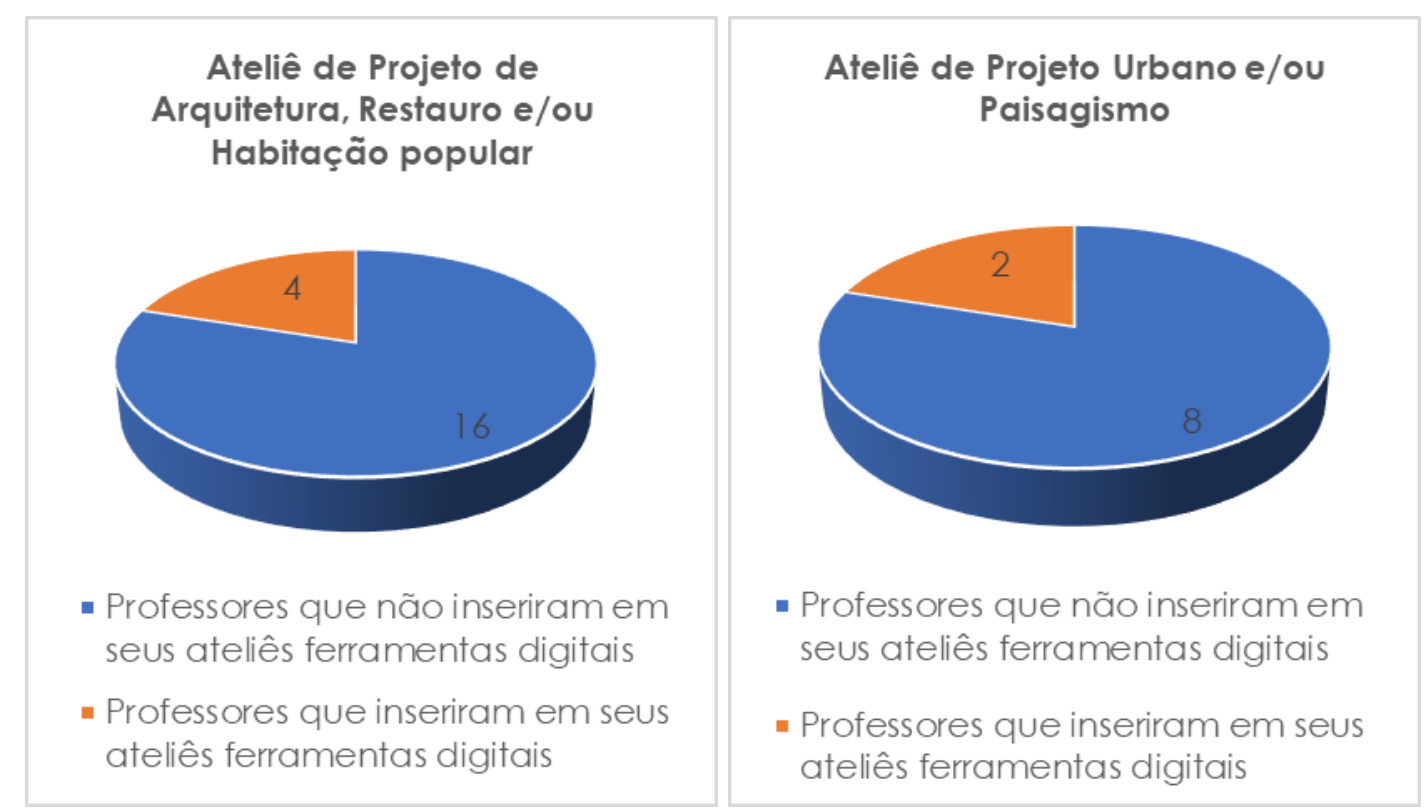

Gráficos 8 e 9 - Quantidade de Professores que inseriram em seus ateliês ferramentas digitais -

Fonte: Autora Queiroz (2019) 


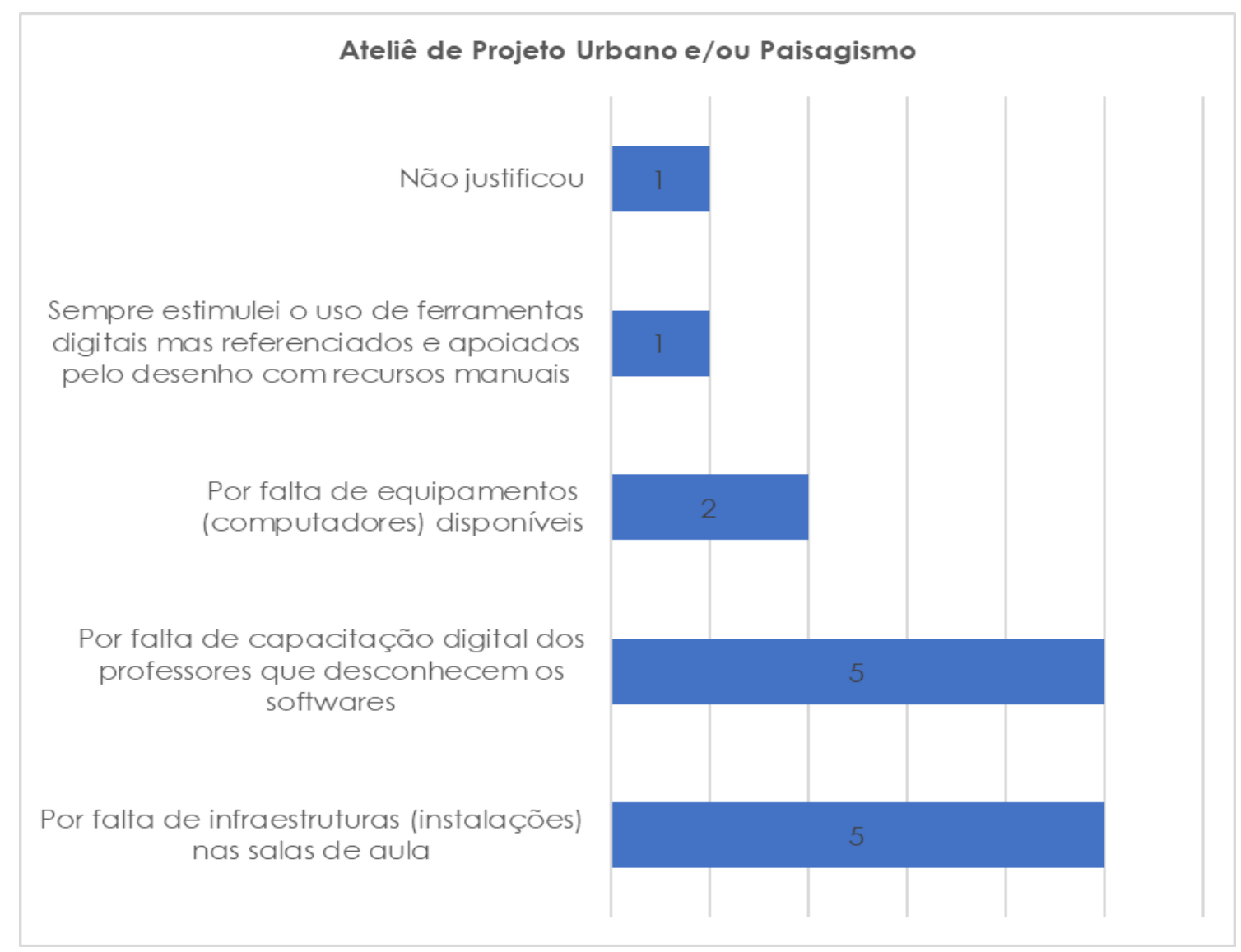

\section{Gráfico 10 - Justificativa dos professores para a não inserção em seus ateliês de ferramentas digitais - \\ Fonte: Autora Queiroz (2019)}

A precariedade da infraestrutura e a limitação física da EAU/UFF também configuram desafios que parecem atravancar a inserção de recursos tecnológicos no ambiente de ensino do projeto. "A falta de espaço físico na escola compromete a inserção de recursos tecnológicos" (PH, 2019, Aluno entrevistado in (oco). A Escola ocupa atualmente duas construções tombadas, popularmente chamadas de Casarão e Chalé (Figura 4).

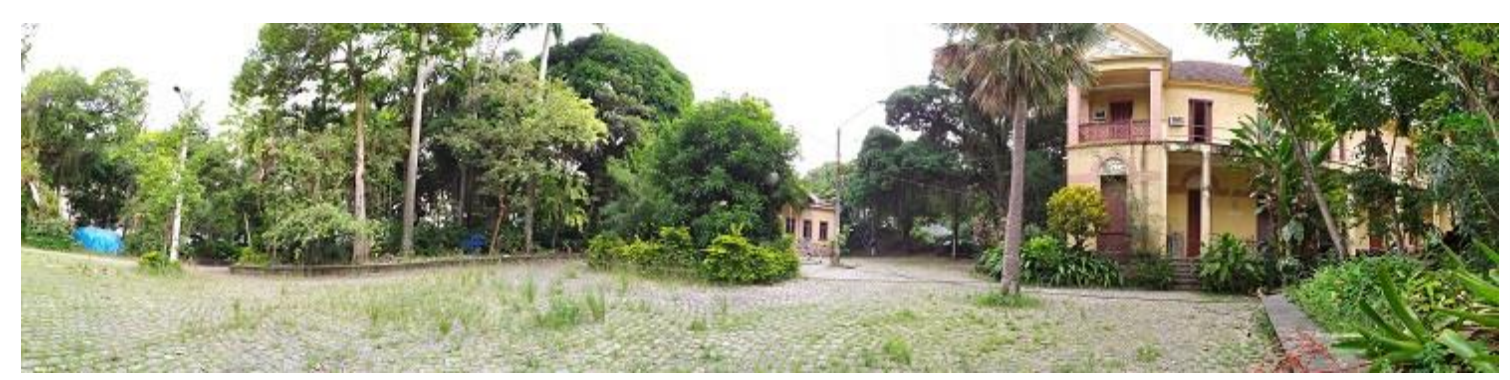

Figura 4 - Casarão e Chalé da EAU/UFF -

Fonte: Autora Queiroz (2019) 


\section{Projeto de Arquitetura, Restauro e/ou Habitação popular}

Na UFF, o meio digital só é permitido a partir de Projeto III. Minhas disciplinas foram Projeto I e II

Porque os alunos estão no inicio do curso

e precisam dominar as ferramentas manuais antes de partir para as digitais

Porque acredito que o ensino do uso das ferramentas deveria se dar nas disciplinas de gráfica digital

Ausência de articulação com os professores que ministram os cursos específicos dessa área.

Por falta de equipamentos (computadores) disponíveis

Por falta de capacitação digital dos professores que desconhecem os softwares

Por falta de infraestruturas (instalações) nas salas de aula

eu, pessoalmente, não incentivo o uso de ferramentas digitais para o desenvolvimento do projeto de arquitetura, prefiro continuar utilizando recursos manuais

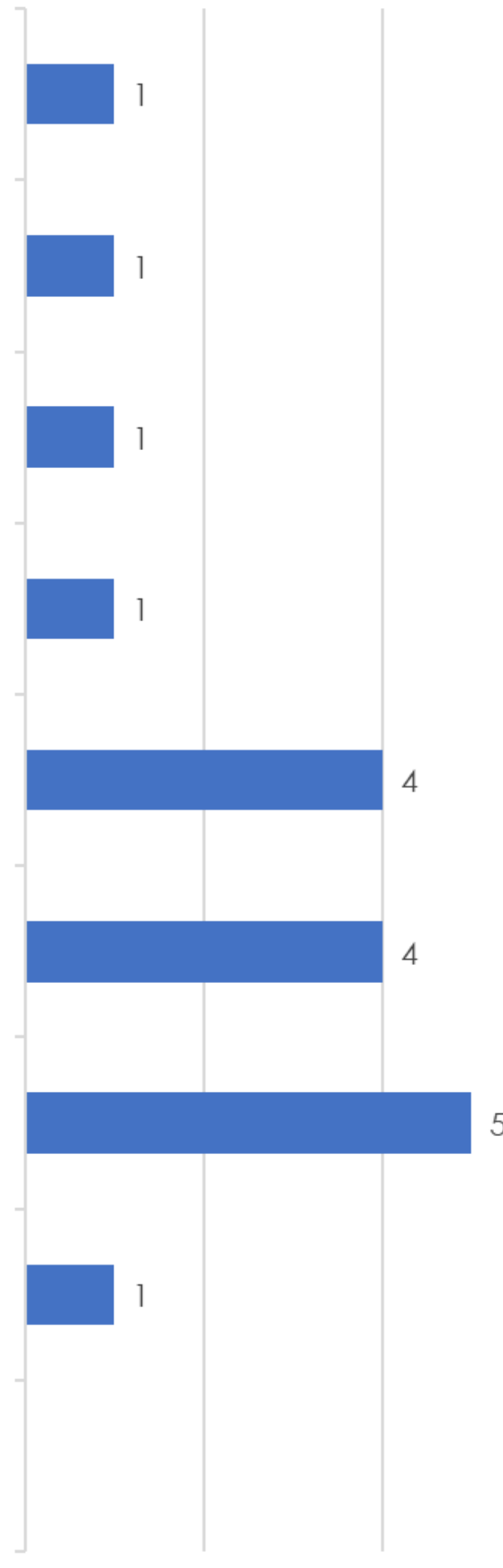

\section{Gráfico 11 - Justificativa dos professores para a não inserção em seus ateliês de ferramentas digitais - \\ Fonte: Autora Queiroz (2019)}

Porém, os ateliês de projeto estão dispostos no quinto andar do prédio pertencente originalmente ao curso de Engenharia, denominado bloco D, que se localiza no mesmo campus (Figuras 5 e 6). 

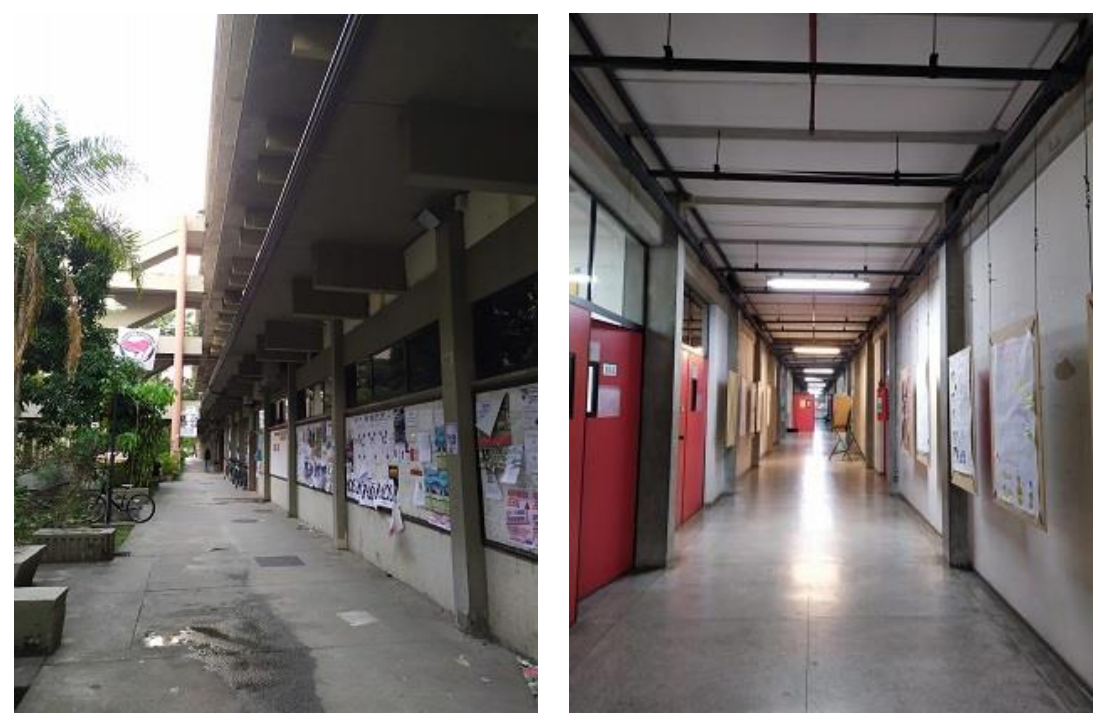

Figuras 5 e 6 - Bloco D: Fachada e Corredor do $5^{\circ}$ andar Fonte: Autora Queiroz (2019)

Apesar dos ateliês ocuparem salas de aula que foram projetadas para funcionar como tal, ao contrário do Casarão ou do Chalé, que são edificações adaptadas, não contemplam uma infraestrutura que atenda equipamentos tecnológicos. Segundo relatos encontrados na pesquisa: "Falta infraestrutura e investimento" (JAC, 2019, Professor-respondente).

Carvalho e Savignon (2012) enumeram os equipamentos que fariam o ateliê de projetos um ambiente tecnologicamente atualizado: pranchetas tradicionais, computadores individuais, mesa digitalizadora, recursos audiovisuais integrados e acesso à internet. Claro e Jordão (2014) garantem, que quando o desenvolvimento do trabalho acontece por meio do uso de novas tecnologias aliadas as anteriores é aberta uma possibilidade de ampliação da capacidade criativa do aluno durante o processo de projeto. Entretanto, para que aconteça é preciso além da superação dos desafios já mencionados, uma análise cuidadosa da relação professor-aluno no contexto contemporâneo da tecnologia.

\subsection{Relação entre professor e aluno em tempos de evolução digital}

Professores e alunos dificilmente pertencem à mesma geração e tem o mesmo contexto de formação. No caso da EAU/UFF, poucos professores tiveram acesso às ferramentas digitais durante sua graduação (gráfico 12), enquanto a maioria dos alunos já entraram na faculdade tendo sido apresentados a uma enormidade de ferramentas, inclusive vinculadas a arquitetura (gráfico 13).

Veloso e Rufino (2005) descrevem como essa dinâmica se tornou desigual:

[...] de um lado, um alunado formado na chamada era digital e das "visitas virtuais", sempre aflito para aprender a usar novos softwares, mesmo sem saber bem como projetar com eles, e, do outro, um professorado em grande parte ainda formado na era "da prancheta" e das "visitas in loco", aflito por não ser compreendido em sua linguagem e raciocínio analógicos (VELOSO; RUFINO, 2005, p. 269). 
Professores que tiveram acesso a ferramentas digitais durante graduação

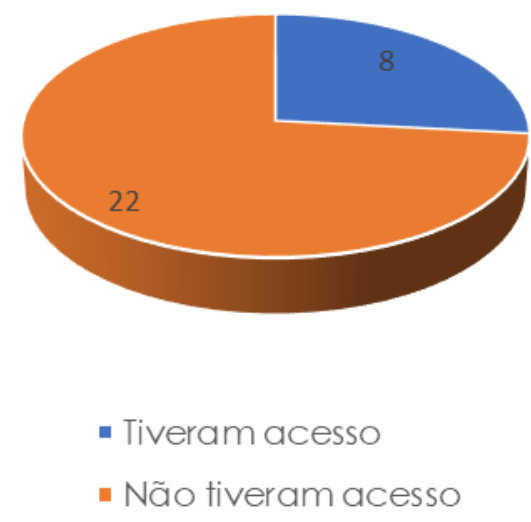

Alunos que tiveram acesso a ferramentas digitais relacionadas a arquitetura antes de ingressarem na graduação

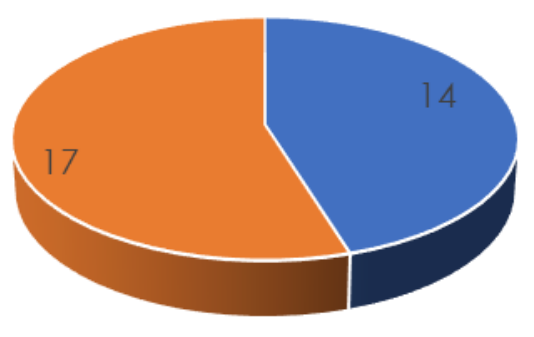

- Tiveram acesso

- Não tiveram acesso

\section{Gráficos 12 e 13 - Professores e Alunos da EAU/UFF que tiveram acesso a ferramentas digitais durante graduação e antes da graduação - \\ Fonte: Autora Queiroz (2019)}

Além dessa diferença de formação, há também uma diferença de atuação. Na EAU/UFF, mesmo havendo um equilíbrio entre professores que mantiveram sua atuação nos últimos 10 anos exclusiva às salas de aula e pesquisas científicas (Gráfico 14) e, professores que também atuaram como arquitetos; a maioria dos alunos durante sua graduação nesse mesmo período se encontrava já imersa no mercado de trabalho, em estágios (gráfico 15). O que pode ter propiciado uma desigualdade entre docentes e discentes referente ao dia-a-dia do uso de ferramentas digitais.
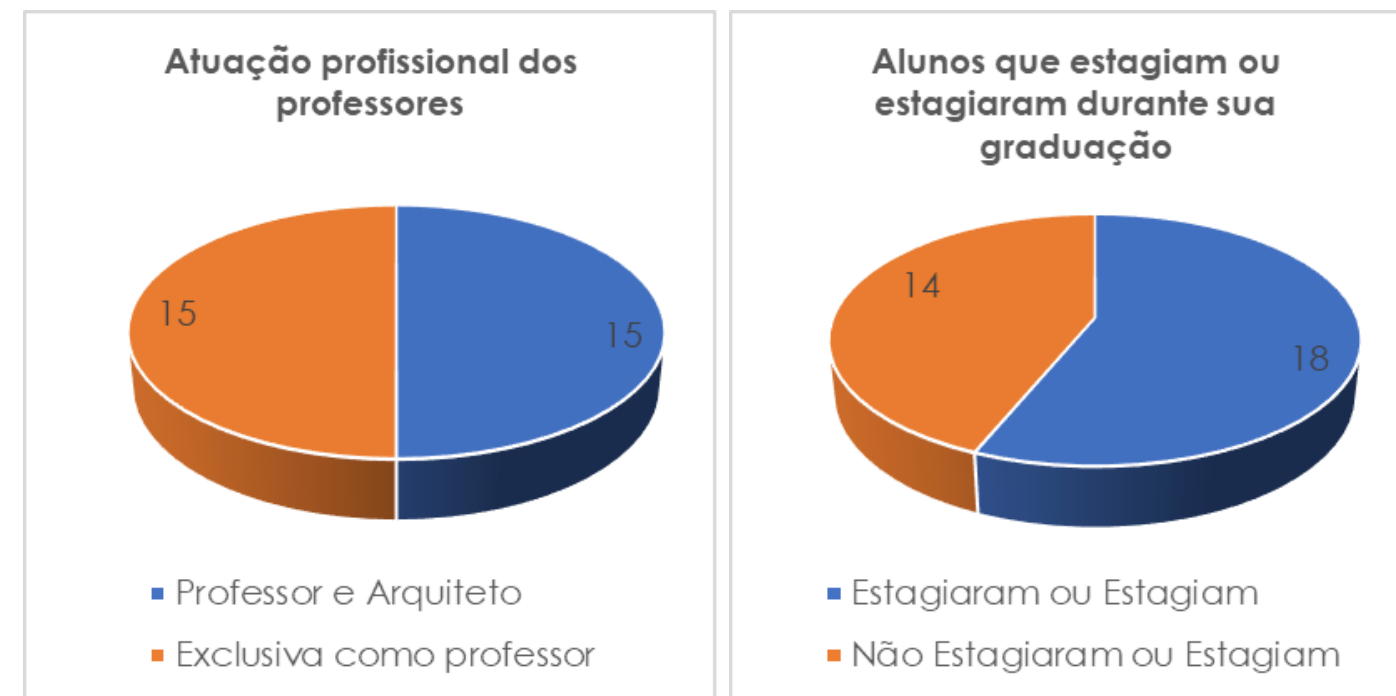
Gráficos 14 e 15 - Atuação profissional dos Professores versus Alunos da EAU/UFF que estagiam ou estagiaram durante sua graduação -
Fonte: Autora Queiroz (2019)

O panorama encontrado na EAU/UFF referente a sensação de distanciamento na relação professor-aluno no que tange a conhecimento digital é pouco 
claro. Nas respostas qualitativas, professores e alunos constatam esse distanciamento: "Até nas disciplinas voltadas ao ensino de softwares são aplicadas por professores que, em geral, não dominam os programas" (CP, 2019, Aluno-respondente). "Falta diminuir a distância entre o conhecimento adquirido pelo aluno e o referente à maioria dos professores (MLPMC, 2019, professor-respondente). Entretanto, nas respostas quantitativas, somente os alunos apontam um distanciamento mais significativo (Gráficos 16 e 17).

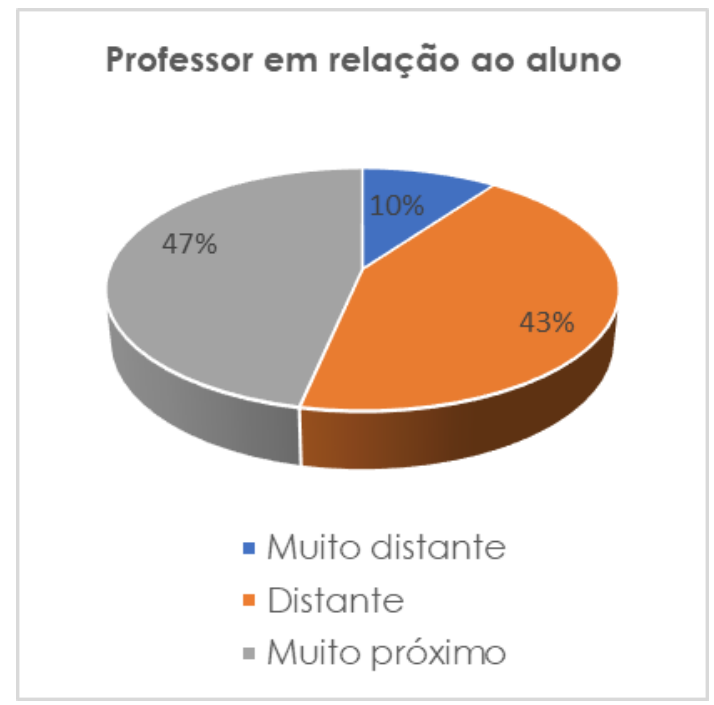

Aluno em relação ao Professor

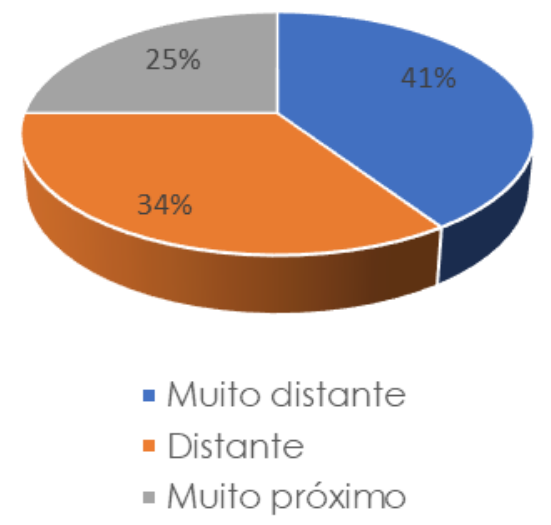

\section{Gráficos 16 e 17 - Comparação das proporções relatadas pelos respondentes em relação à sensação de distanciamento referente a conhecimento digital - Fonte: Autora Queiroz (2019)}

Quanto ao status da EAU/UFF frente a evolução tecnológica, discentes e docentes tem a mesma perspectiva, pois a maioria acredita que a Escola não está em consonância no que se refere ao uso de ferramentas digitais (Gráficos 18 e 19):
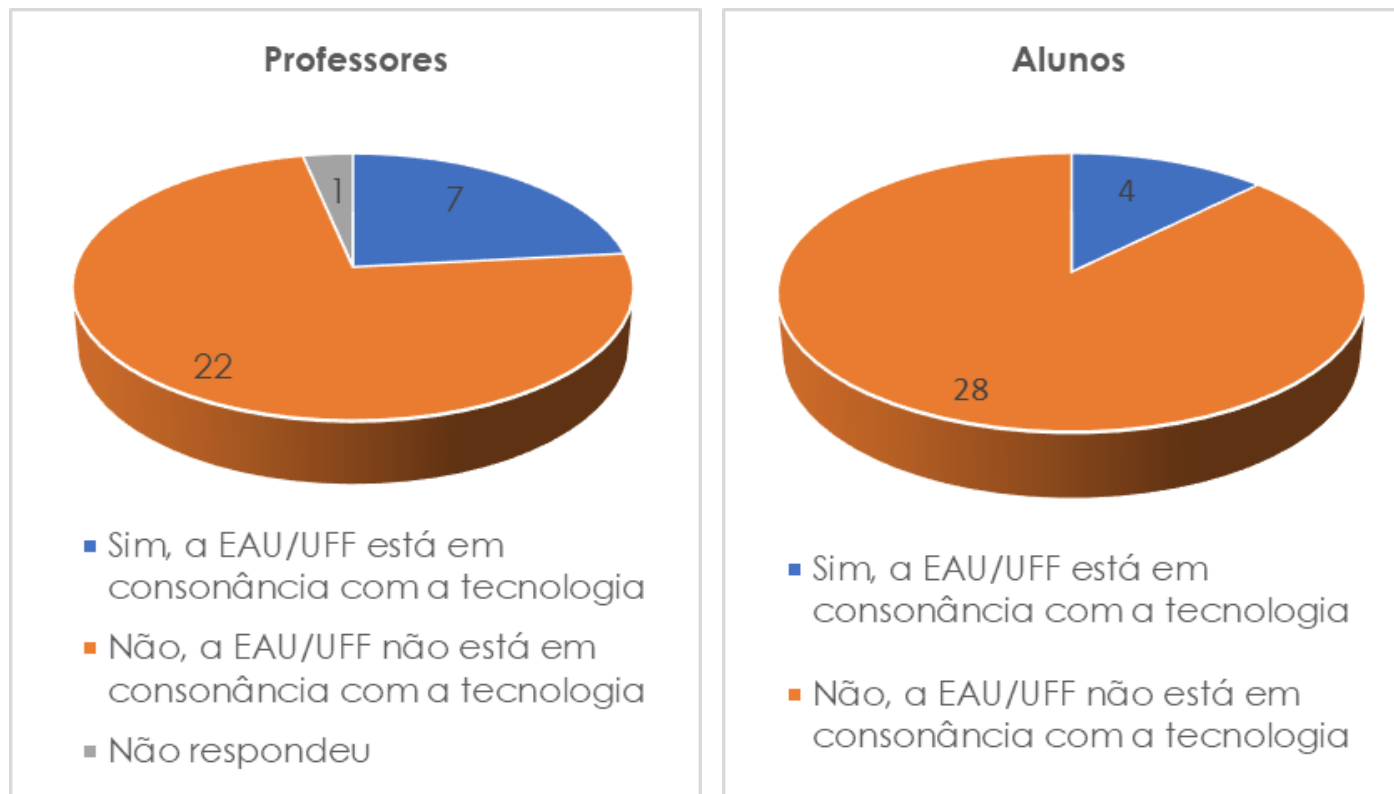

Gráficos 18 e 19 - Comparação das proporções relatadas pelos respondentes em relação à opinião individual se a EAU/UFF está em consonância com a tecnologia Fonte: Autora Queiroz (2019) 
Ensino defasado, conteúdo muito básico, pouca oferta de softwares ensinados. Renderização é fundamental e não é ensinada. As atividades desenvolvidas nas disciplinas são voltadas para conhecimentos a serem aplicados em outras disciplinas, mas não atendem as expectativas do que exigido em escritórios de arquitetura (MJ, 2019, Aluno-respondente).

Professores desatualizados, equipamento idem. Não apenas frente ao mercado, mas frente ao desenvolvimento da tecnologia. Minha escola (EAU/UFF) subestima inteiramente 0 tema (recursos digitais no ensino) (VMN, 2019, Professorrespondente).

Diante da utilização das tecnologias, o papel do professor é além de mediar a relação do aluno e do conhecimento, é também intermediar o uso das ferramentas digitais pelos alunos. Wojcickoski (2017) sugere que de acordo com cada etapa do projeto, cabe ao professor orientar o aluno sobre qual a melhor forma de utilizar os meios e qual situação determinado meio se faz mais efetivo. Um professor da EAU/UFF faz uma síntese nesse sentido:

A grande transformação dentro do ensino deve se dar pelas ementas e programas das disciplinas, que ainda apresentam, em seu conjunto, uma lógica separadora de conhecimentos/capacitações (RLDT, 2019, Professorrespondente).

Segundo Dertouzos (2000), "a educação é acender a chama da vontade de aprender no coração dos estudantes, dar o exemplo e criar vínculos entre professores e alunos".

\section{CONSIDERAÇÕES FINAIS}

A introdução de ferramentas digitais no ensino precisa ser criteriosa. O estímulo ao ensino digital deve partir da instituição ao oferecer meios que propiciem a inserção tecnológica nas práticas docentes, para que então o professor transmita seus conhecimentos e monitore o uso das ferramentas digitais nas suas aulas. Conclui-se, portanto, que uma mistura híbrida entre as ferramentas, manual e digital, seja a perspectiva ideal. E, para tanto, precisa ser gerenciada.

A sociedade tecnológica deve considerar que o treinamento das habilidades manuais precisa acontecer obrigatoriamente, independente da ferramenta que seja disponibilizada, papel ou tablet. A discussão sobre a inserção de ferramentas digitais precisa ser superada à mera questão do desenho manual e da representação projetual, desatando todos os nós, desde a atualização dos professores à adequação dos espaços físicos, para que se evite a formação de arquitetos com pouca habilidade no traço manual.

Por fim, a distribuição de ferramentas digitais ao longo do curso, numa inserção progressiva e vinculada à necessidade disciplinar de cada conteúdo programático é o caminho para que as habilidades manuais não sejam suprimidas e/ou menosprezadas e, ao mesmo tempo, a realidade digital não seja mais ignorada. 


\section{AGRADECIMENTOS}

Aos professores e alunos da EAU/UFF que se dispuseram a responder os questionários.

\section{REFERÊNCIAS}

BOTASSO, G. B.; VIZIOLI, S. H. T. Desenho e processo projetivo: aproximações entre Eduardo Souto de Moura e Eduardo de Almeida. In: INTERNATIONAL CONFERENCE ON GRAPHICS ENGINEERING FOR ARTS AND DESIGN, XII, 2017, Araçatuba. Anais Eletrônicos...Araçatuba: Graphica, 2017. Disponível em: <https://even3.blob.core.windows.net/anais/49628.pdf>. Acesso em: 13 abr. 2019.

BRASIL. Lei no 8112, de 11 de dezembro de 1990. Política e as Diretrizes para o Desenvolvimento de Pessoal da administração pública federal direta. Art. 10 e $\S 1^{\circ}$ do Decreto $n^{\circ}$ 5.707/2006 com redação dada pelo Decreto $n^{\circ}$ 9.1 49/2017. Disponível em: <http://www.planalto.gov.br/ccivil_03/leis/l81 12cons.htm>. Acesso em: 14 jan. 2019.

CARVALHO, R. S.; SAVIGNON, A. P. O professor de projeto de arquitetura na era digital: desafios e perspectivas. Gestão e Tecnologia de Projetos, v. 6, n. 2, p. 4-13, jan. 2012. Disponível em: <http://www.revistas.usp.br>. Acesso em: 27 nov.2018.

CASTRAL, P. C.; VIZIOLI, S. H. T. O desenho à mão-livre mediado pela tablete. In: CONGRESSO SIGRADI, XV. 2011 . FADU-UNL. Santa Fé, Argentina, 2011, p. 64-67. Disponível em:

<http://papers.cumincad.org/data/works/att/sigradi2011_121.content.pdf>. Acesso em: 10 abr.2019.

CLARO, M. A.; JORDÃO, L. C. S. O ensino em projeto de Arquitetura frente às inovações tecnológicas - Um processo Reflexivo. Caderno Abea, v. 39, p.

117-127, out. 2014. Disponível em: <http://www.abea.org.br/>. Acesso em: 15 abr.2019.

DERTOUZOS, M. O que será: como a informação transformará nossas vidas. São Paulo: Companhia das Letras, 2000.

FLORIO, W. O croqui no atelier de projeto: desafios no ensino de arquitetura na era digital. Revista Brasileira de Expressão Gráfica, v. 1, n. 1, p. 50-76, 2013. Disponível em: <https://goo.gl/49CXAc>. Acesso em: 27 nov.2018.

GABRIEL, M. Educ@r - A (r)evolução digital na educação. São Paulo: Saraiva, 2013.

GREEN, B.; BIGUM, C. Alienígenas em sala de aula. Tradução de Tomaz Tadeu da Silva (org.) Petrópolis: Vozes, 1995.

MARTINEZ, A. C. Ensaio sobre o projeto. Brasília: Universidade de Brasília, 2000.

VELOSO, M.; RUFINO, I. A. A. Entre a bicicleta e a nave espacial: os novos paradigmas da informática e o ensino do projeto arquitetônico. In: DUARTE. C. et al. (Org.). O lugar do projeto no ensino e na pesquisa em arquitetura e urbanismo. Rio de Janeiro: Contracapa, 2007. Disponível em: <https://www.researchgate.net/publication/267776275_ENTRE_A_BICICLETA_E_ A_NAVE_ESPACIAL_- 
OS_NOVOS_PARADIGMAS_DA_INFORMATICA_E_O_ENSINO_DO_PROJETO_ARQ UITETONICO>. Acesso em: $20 \mathrm{fev} .2019$

WOJCICKOSKI, V. G. A hibridação dos meios de representação no Atelier de Projeto. Caderno Abea, v. 41, p. 260-274, out. 2017. Disponível em:

<http://www.abea.org.br/>. Acesso em: 15 abr.2019. 